\title{
In Focus
Spotlight on the December 2 Issue
}

\author{
Robert A. Gross, MD, PhD, FAAN \\ Editor-in-Chief, Neurology ${ }^{\circledR}$
}

\section{Deaths from stroke in US young adults, 1989-2009}

This study of ischemic and hemorrhagic stroke found that overall stroke mortality in young adults is decreasing, but mortality from ischemic stroke has declined more slowly in younger adults compared to older adults. These findings suggest the need to understand why and how the slower decline in mortality from ischemic stroke differs between younger and older adults.

See p. 2110; Editorial, p. 2102

\section{Changing outcome in inflammatory neuropathies: Rasch-comparative responsiveness}

Patient-based improvements were identified using the Inflammatory Rasch-built Overall Disability Scale compared to traditional scales in Guillain-Barré syndrome and chronic inflammatory demyelinating polyradiculoneuropathy. These findings may simplify and standardize daily practice and increase the awareness regarding types of data and minimum clinically important differences, a beneficial concept to our field.

See p. 2124

From editorialists Smith \& Burns: "Despite its appeal, Rasch analysis remains a challenging concept for most clinicians, necessitating better training in clinimetrics and provision of more understandable explanations of its methodology, strengths, and limitations before it can gain widespread acceptance."

See p. 2104

\section{Sporadic late-onset nemaline myopathy with MGUS:} Long-term follow-up after melphalan and SCT $\mathbb{a}$ 金

This case series shows the positive effect of high-dose melphalan (HDM) followed by autologous stem cell transplantation (SCT) in nemaline myopathy with monoclonal gammopathy of undetermined significance. Seven patients showed a lasting moderate-good clinical response, 2 of them after the second HDM-SCT, suggesting that this treatment increases the probability of survival and functional improvement.

See p. 2133

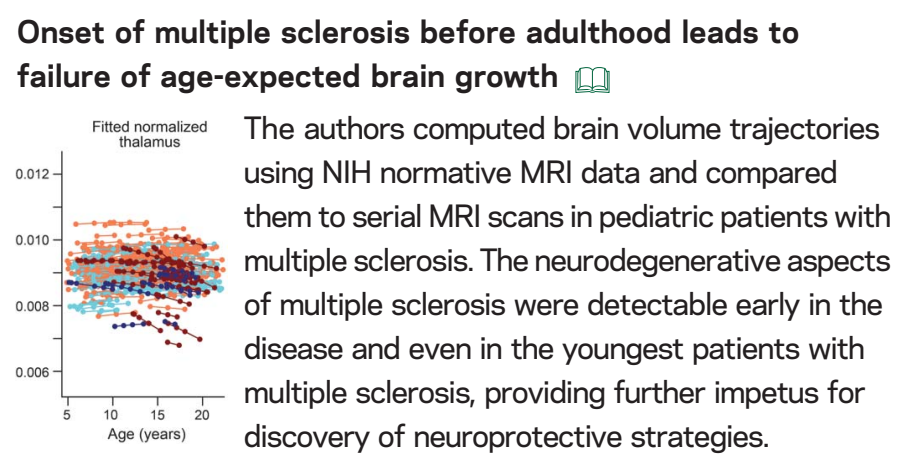

See p. 2140; Editorial, p. 2106

Functional-structural correlations in the afferent visual pathway in pediatric demyelination

The authors evaluated 37 children with demyelinating disorders using a visual battery including optical coherence tomography. They found an average $20 \%$ decrease in ganglion cell layer thickness after a single clinical event. This evidence of early damage to retinal architecture suggests the retina may be a primary site of injury.

See p. 2147; Editorial, p. 2108

Improving functional disability and cognition in Parkinson disease: Randomized controlled trial OPEN

The integrative cognitive training program REHACOP, administered in a group format over 3 months, improved processing speed, visual memory, theory of mind, and functional disability in Parkinson disease. These findings support the integration of cognitive training into the standard of care for patients with Parkinson disease.

See p. 2167

A homozygous splice-site mutation in CARS2 is associated with progressive myoclonic epilepsy

This article describes a novel gene associated with myoclonic epilepsy with ragged red fibers (MERRF) syndrome. Using wholeexome sequencing and analysis of messenger RNA, a splice-site mutation in CARS2 causing exon skipping was observed. Therefore, analysis of CARS2 should be considered for molecular diagnosis of patients with MERRF syndrome. See p. 2183

NB: "DRESS associated with perampanel administration in a child with drug-resistant epilepsy," see p. 2188. To check out other Clinical/Scientific Notes, point your browser to Neurology.org. 


\section{Neurology}

\section{Spotlight on the December 2 Issue}

Robert A. Gross

Neurology 2014;83;2101

DOI 10.1212/WNL.0000000000001061

\section{This information is current as of December 1, 2014}

\section{Updated Information \&}

Services

Permissions \& Licensing

Reprints including high resolution figures, can be found at: http://n.neurology.org/content/83/23/2101.full

Information about reproducing this article in parts (figures,tables) or in its entirety can be found online at:

http://www.neurology.org/about/about_the_journal\#permissions

Information about ordering reprints can be found online:

http://n.neurology.org/subscribers/advertise

Neurology ${ }^{\circledR}$ is the official journal of the American Academy of Neurology. Published continuously since 1951, it is now a weekly with 48 issues per year. Copyright @ 2014 American Academy of Neurology. All rights reserved. Print ISSN: 0028-3878. Online ISSN: 1526-632X.

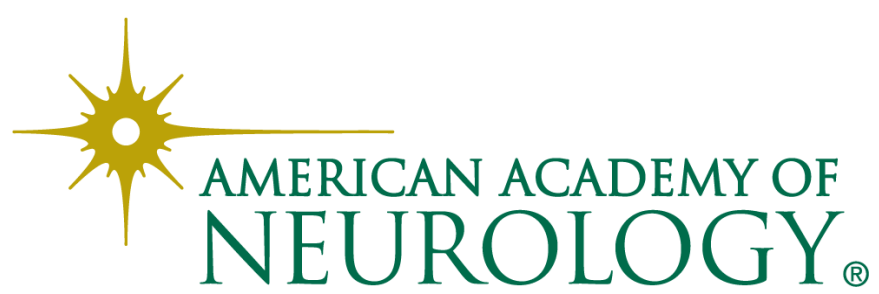

